Әлімжанова Әйгерім*, магистрант

Куратова О.А., к.п.н., профессор Университет иностранных языков и деловой карьеры

г. Алматы, Казахстан

E-mail*: esetovna95@mail.ru

ORCID ID* 0000-0003-2443-9248

\title{
ОСНОВЫ ИНТЕГРАТИВНО-МОДУЛЬНОГО ОБУЧЕНИЯ В ПОДГОТОВКЕ БУДУЩИХ УЧИТЕЛЕЙ ИНОСТРАННОГО ЯЗЫКА
}

\author{
Aigerim Alimzhanova*, Master's Degree student \\ Kuratova O.A., PhD in Pedagogic sciences, Professor \\ University of Foreign Languages and Business Career \\ E-mail*: esetovna95@mail.ru \\ ORCID ID* 0000-0003-2443-9248
}

\section{BASES OF INTEGRATIVE-MODULAR TRAINING IN FUTURE FOREIGN LANGUAGE TEACHERS PREPARATION}

\begin{abstract}
Annotation: This article discusses the implementation of the technology of integrative-modular education in foreign language education and in education in general. The definitions of such concepts as "technology", "learning technology", "module", "modular learning", and of course, "integrativemodular learning" are given. The advantages of modular technologies in the context of the competence approach are presented. The distinctive features of integrative-module training are highlighted.

Keywords: technology, learning technology, module, integrative-modular learning, foreign language, competence-based approach.
\end{abstract}

Аннотация: В данной статье рассматривается реализация технологии интегративномодульного обучения в иноязычном образовании и в образовании в целом. Приводятся определения таких понятий как: «технология», «технология обучения», «модуль», «модульное обучение», и конечно же, «интегративно-модульное обучение». Представлены преимущества модульной технологий в контексте компетентностного подхода. Выделены отличительные черты интегративно-модульного обучения.

Ключевые слова: технология, технология обучения, модуль, интегративно-модульное обучение, иностранный язык, компетентностный подход.

Приоритетной задачей преподавателей высших учебных заведений на сегодняшний день является не преподнесение готового материала в виде лекции, конспектов и слайдов, а развитие самостоятельного изучения дисциплины студентами, в том числе и вне университета, формирование критического мышления, индивидуальной точки зрения, коммуникативной компетентности и навыков адаптировать материалы под определенные ситуации. Сложившаяся к настоящему времени система подготовки педагогических кадров требует существенных изменений. Высшая школа должна создавать условия для интеллектуального, творческого и нравственного развития личности и общества в целом. И это задача не столько самого содержания образования, сколько используемых технологий обучения.

Однако, одной из главнейших проблем профессионального образования на современном этапе развития является незначительная разработанность технологий. Решение этих проблем связано с проектированием новой образовательной методологий, 
обеспечивающей достижение высокого уровня качества и гарантированных результатов профессионального обучения и становления личности преподавателя. Педагогическое мастерство состоит в том, чтобы вычленить из огромного количества информации нужное содержание в соответствии с государственным стандартом высшего профессионального образования и поставленными задачами, а также применить оптимальные технологии обучения. Технология интегративно-модульного обучения являясь одним из последних направлений индивидуализированного обучения, способствует решению поставленных задач применительно к преподаванию иностранного языка в контексте компетентностного подхода.

Согласно толковому словарю Ожегова С.И. «технология» (от др.-греч. $\tau \dot{\varepsilon} \chi \vee \eta-$

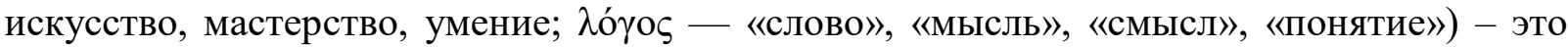
совокупность производственных методов и процессов в определённой отрасли производства, а также научное описание способов производства. Технология обучения, в свою очередь, представляет собой способ реализации содержания обучения, предусмотренного учебными программами, представляющими систему форм, методов и средств обучения, обеспечивающую эффективнейшее достижение поставленных целей. С одной стороны, технология обучения - это совокупность методов и средств обработки, представления, изменения и предъявления учебной информации, а с другой - это наука о способах воздействия преподавателя на качество мышления студентов в процессе обучения с использованием необходимых средств.

Как одно из наиболее исследуемых в научной области за последние десятилетия, понятие «модуль» применяется и в педагогической теории, а именно в общей системе обеспечения качества и управления качеством современного образования. Ученые умы западных стран определяют «модуль» как обучающий замкнутый комплекс, в состав которого входят: в первую очередь сам педагог, обучаемые, учебный материал и средства, помогающие обучающемуся и преподавателю реализовать индивидуализированный подход, обеспечить их взаимодействие.

Один из числа первоисследователей данной научной среды П.А. Юцявичене понимает «модуль» как «блок, состоящий из нескольких рядов информации, которые включают в себя логически завершенную единицу учебного материала, целевую программу действий и методическое руководство, обеспечивающее достижение поставленных дидактических целей». При этом содержание учебной дисциплины может быть представлено в модуле на трех уровнях, а именно: полном, сокращенном и углубленном. Подобная организация учебного материала с учетом основных положений индивидуально-дифференцированного обучения соответствует персонифицированному характеру иноязычного образования в контексте реализации компетентностного подхода.

Следовательно, модульное обучение - это способ организации учебного процесса на основе блочно-модульного представления учебной информации. А сущность модульного обучения заключается в том, что содержание самого обучения структурируется в автономные организационно-методические комплексы - то есть модули, объем и содержание которых могут меняться в зависимости от дидактических целей, профильной и уровневой дифференциации обучающихся, желании обучающихся по выбору индивидуальной траектории движения по учебному курсу.

Стоит отметить, что базирование учебного процесса по схожим с «Иностранным языком» дисциплинам на основе модульной технологии обладает рядом преимуществ по сравнению с традиционным подходом к обучению иностранному языку в высшей школе, а именно: 
- тщательный отбор и структурирование содержания обучения осуществляются на деятельностной основе с целью системного овладения учебным материалом, расширения горизонта фоновых знаний, комплексного формирования и развития умений и навыков во всех видах иноязычно -речевой деятельности;

- алгоритм обучения представляется в отдельных блоках, усвоение которых осуществляется в соответствии с дидактической целью, формулирующиеся для обучающегося и содержащей не только указание на диапазон изучаемого содержания, но и на уровень его усвоения;

- интегрируются разные ступени иноязычной подготовки студентов и, соответственно, сокращается разрыв между возникшими в последние годы высокими требованиями к уровню владения иностранным языком и ограниченным количеством учебных часов, выделяемых на его изучение;

- программу обучения приспосабливают к уровню подготовки студента с целью продвижения каждого обучающегося на более высокий уровень;

- здесь используют различные формы работы с учебным материалом, которые способствуют созданию предпосылок для творческой деятельности студента;

- реализуется пошаговый контроль результатов обучения, составляется и ведется индивидуальный рейтинг обучаемого;

- акцентируется самостоятельность и частичная независимость студента при положительных результатах на пути к четко обозначенной цели, что делает возможным осознание им себя в деятельности, определение уровня усвоения знаний, видение проблем в своих учебных достижениях;

- наблюдается значительный профессиональный рост преподавателя в процессе овладения им модульной технологии обучения.

Термин «интегративно-модульное обучение» в свою очередь является очень объемным понятием, и в современной педагогике оно означает представление учебного процесса, при котором вся учебная информация подразделяется на определенное количество модулей. Совокупность нескольких модулей позволяет раскрыть содержание определенной учебной тематики или даже всей учебной дисциплины. Отличительными чертами интегративно-модульного обучения от иных технологий приходятся:

- содержание обучения представляется в законченных, самостоятельных блоках - модулях, одновременно являющихся банком информации и методическим руководством по его усвоению;

- с помощью модулей обеспечивается осознанное самостоятельное достижение обучаемыми определенного уровня предварительной подготовленности к каждому занятию;

- неизбежно соблюдаются паритетные субъект-субъектные взаимоотношения между педагогом и обучаемыми в учебном процессе.

Изложенное выше позволяет сделать вывод о том, что технология интегративно модульного обучения - это не просто педагогическая технология, применяемая при обучении студентов иностранному языку, а необходимое условие овладения иноязычной культурой посредством создания благоприятных условий для развития будущих специалистов как культурно-языковых личностей, владеющих высокоразвитыми коммуникативно-культурными умениями при решении будущих профессиональных задач. Данная технология обучения содержит возможности индивидуализации учебного процесса с учетом требований компетентностного подхода, выбора уровня сложности и оптимального пути изучения в зависимости от уровня базовой подготовленности каждого студента по результатам первых тестов (срезов, контрольных). 
Для повышения эффективности обратной связи предусмотрены различные виды контроля качества усвоения материала: входной и выходной контроль при прохождении каждого проблемного модуля и модульной программы в целом, тесты для самоконтроля внутри каждого учебного элемента. Все это должно способствовать повышению качества профессионально направленных знаний и умений студентов.

\section{Литература}

1. Ожегов С. И. Словарь русского языка / Под общ. ред. проф. Л. И. Скворцова. - 24-е изд., испр.. - М.: Оникс, Мир и Образование, 2007. - 1200 с.

2. Новые педагогические и информационные технологии в системе образования: учеб. Пособие для студ. пед. вузов и системы повыш. квалиф. пед. кадров /под ред. Е.С. Полат. - М.: Академия, 2003. - 272 с.

3. Юцявичене П.А. Теория и практика модульного обучения. - Каунас, 2009. - 271 с.

4. Туребаева К.Ж., Жусупова Ж.А. Место модульного обучения в современном профессиональном образовании // Вестник КазНП: сб. статей. - Алматы, 2018

5. Фахретдинов Т.Р., Пестова О.Г. Место модульного обучения в системе инновационных образовательных технологий // Научно-методический электронный журнал «NovaInfo», 2018. - URL: https://novainfo.ru/article/14989 (дата обращения 20.09.2018) 